\title{
The issues of drainage of discussed mines in the Katowice conurbation, Poland
}

\author{
Marzena Lamparska
}

Department of Economic Geography, Faculty of Earth Sciences, University of Silesia, Będzińska Str. 60, 41-200 Sosnowiec, Poland E-mail address: marzenalamparska@gmail.com

\begin{abstract}
The Katowice conurbation is situated in the Upper-Silesian Coal Basin, in a region which had high rate of water inflow in the pre-mining period. In order to make deposits of mineral resources accessible, it was, and still is, necessary provide mines with a draining system, which now reaches as deep as $1200 \mathrm{~m}$. The area of the depression sink which was thus created is about $1200 \mathrm{~km}^{2}$. Currently, all metal ore mines within the conurbation, as well as part of coal mines, have been closed down, but water which flows into them is still pumped out due to the legal obligation to protect neighbouring operating mines. After the operation and drainage of mines cease, water coming to abandoned excavations will begin restoring static reserves in the orogen, which, depending on hydrological conditions, will take between several and a few dozen years. As the level of underground water rises, the process of subsidence of old shallow mining excavations will intensify, and many depressions may appear in highly urbanized areas. In areas of mining subsidence, the underground water-table will be close to the surface, causing flooding of basements and building foundations, and the deepest subsidence basins will probably be completely flooded. Current location of operating mines on the northern and southern sides of the conurbation with the central belt of drained excavations is unfavourable for its sustainable development. A solution, which would make it possible for the conurbation to grow, would be to close down and flood the mines on the northern side as soon as their mining concessions expire, which will be in early 2020s. Then, the area would regain its original stability within a decade and all kinds of construction activities could be carried out there. That, however, requires authorities of municipalities to object to the extension of concessions for mines, which may be impossible to obtain due to fears of social discontent resulting from miners - residents of those municipalities - being made redundant.
\end{abstract}

KEY WORDS: mining, groundwater, Upper-Silesian Coal Basin, mining damage

\section{Introduction}

The Katowice conurbation is situated in the region which was characterized by a high rate of water inflow before coal mining activities started there. Quaternary deposits included subcutaneous and groundwater coming from precipitation, which had contact with still and running surface water. From those water-bearing layers, water infiltrated inside, to Triassic and Carboniferous layers with the water table remaining at 20-30 metres under the surface of the ground and restricting the mining range of old metal ore and coal mines. Making deposits of mineral resources below the underground water level accessible required draining of mines - on the turn of the $21^{\text {st }}$ century, draining reached as deep as $1200 \mathrm{~m}$.
Mine draining has a negative impact on the environment. It results in a shortage of water in streams, rivers and wells, as well as hampering of biological processes in rivers where drained water is discharged. Currently, all metal ore mines and some of the coal mines in the Katowice conurbation have been closed down, but the water which flows into them is still pumped out because of a legal obligation to protect neighbouring operating mines (Tab. 1). Extended drainage of old mining excavations results in necessity to protect new civil structures in post-mining areas. This is so because foundation soil is not stabilized until a long time after a mine is closed down, when abandoned excavations are flooded and restoring water-table eventually sets the zones of wetland and flood land. 
The legal aspect of mine drainage is important, because act-induced length of this obligation expires many years before the water-table is finally restored and impact of the mining activity finishes. Next proprietors of post-mining areas, and most frequently these are municipalities, may thus have to overtake the responsibility for removing mining damage caused at the final stage of water-table level restoration (LAMPARSKA-STOBIECKA, 2008). Thus, the documents regulating purchase or acquisition of post-mining lands should include precise provisions regarding duties of all parties.

Table 1. Abandoned and combined black coal mines in the Katowice conurbation (made by the author on the base of Bilans zasobów kopalin, 2011)

\begin{tabular}{|c|c|}
\hline Abandoned black coal mines & $\begin{array}{c}\text { Merged black coal mines } \\
\text { (with limited mining regions) }\end{array}$ \\
\hline $\begin{array}{ll}\text { 1. } & \text { KWK Gliwice in Gliwice } \\
\text { 2. } & \text { KWK Pstrowski in Zabrze } \\
\text { 3. } & \text { KWK Miechowice in Bytom } \\
\text { 4. } & \text { KWK Szombierki in Bytom } \\
\text { 5. } & \text { KWK Rozbark in Bytom } \\
\text { 6. } & \text { KWK Powstańców Śląskich in Bytom } \\
\text { 7. } & \text { KWK Jowisz in Wojkowice } \\
\text { 8. } & \text { KWK Grodziec in Będzin - Grodziec } \\
\text { 9. } & \text { KWK Saturn in Czeladź } \\
\text { 10. } & \text { KWK Paryż in Dąbrowa Górnicza } \\
\text { 11. } & \text { KWK Sosnowiec in Sosnowiec } \\
\text { 12. } & \text { KWK Porąbka - Klimontów in Sosnowiec } \\
\text { 13. } & \text { KWK Niwka Modrzejów } \\
\text { 14. } & \text { KWK Siemianowice in Siemianowice Śl. } \\
\text { 15. } & \text { KWK Rozalia in Siemianowice Śl. } \\
\text { 16. } & \text { KWK Jan Kanty in Jaworzno } \\
\text { 17. } & \text { KWK Katowice (Katowice - Kleofas) in Katowice } \\
\text { 18. } & \text { KWK Barbara - Chorzów in Chorzów } \\
\text { 19. } & \text { KWK Dębieńsko in Czerwionka } \\
\text { 20. } & \text { KWK Walenty Wawel in Ruda Śląska }\end{array}$ & $\begin{array}{l}\text { 1. KWK Centrum in Bytom and KWK Bobrek in } \\
\text { Bytom reduced to ZG Centrum - Bobrek in Bytom } \\
\text { 2. KWK Julian in Piekary Śl. and KWK Andaluzja in } \\
\text { Piekary-Brzeziny Śl. reduced to ZG Piekary in } \\
\text { Piekary Śl. } \\
\text { 3. KWK Polska in Świętochłowice incorporated in } \\
\text { ZG Polska-Wirek in Ruda Śl. } \\
\text { 4. KWK Zabrze in Zabrze incorporated in KWK } \\
\text { Zabrze-Bielszowice in Ruda Śl. } \\
\text { 5. KWK Bolesław Śmiały w Łaziskach reduced to } \\
\text { KWK Łaziska in Łaziska } \\
\text { 6. KWK Sośnica in Gliwice and KWK Makoszowy in } \\
\text { Zabrze connected as KWK Śośnica-Makoszowy } \\
\text { in Zabrze } \\
\text { 7. KWK Wujek in Katowice and KWK Śląsk in Ruda } \\
\text { Śl. connected as KWK Wujek in Katowice } \\
\text { 8. KWK Knurów in Knurów and KWK Szczygłowice } \\
\text { in Knurów connected as KWK Knurów- } \\
\text { Szczygłowice in Knurów } \\
\text { 9. A small private mining plant (SILTECH) was set } \\
\text { up within former Mining Region KWK Pstrowski, } \\
\text { mining remaining reserves of deposit "Gigant” }\end{array}$ \\
\hline
\end{tabular}

\section{Issues related to drainage of mineral resource deposits}

The Katowice conurbation is situated in the Upper-Silesian Coal Basin, the region of over 200 years long intensive mining of hard coal and zinc and lead ores combined with just as intensive draining of the orogen which makes mining possible. As a result of long-lasting mining and draining of mines, the terrain sinks and subsidence is as deep as 20-30 metres in many places, reaching over $30 \mathrm{~m}$ in the northern part of Bytom (DULIAS, 2003; CABAŁA ET AL., 2004; SOLARSKI \& PRADELA, 2010). Subsidence of the land in the Katowice conurbation resulted in significant changes in the hydrographic network, further increased by added results of other economic activities (JANKOWSKI, 1987; CZAJA, 1999). As the mining industry developed, more and more saline water was drained from mines; large part of this water is discharged to rivers, which causes dramatic deterioration of their water.

As a result of mine draining, a compact depression sink, about $1200 \mathrm{~km}^{2}$ in area, formed in the Katowice conurbation, in Carboniferous deposits (WILK, 2003;
BILANS ZASOBÓW KOPALIN, 2007; LAMPARSKA-STOBIECKA, 2008). Also, Triassic and permeable Quaternary deposits overlying directly Carboniferous deposits were drained. Triassic deposits, formed mainly as impermeable clayey deposits, were affected by drainage to an insignificant extent.

Because of running out of balanced deposits of mining resources, all metal ore mines and several coal mines have been closed down in the Katowice conurbation. In spite of closing them down, however, draining has to be continued in order to protect operating mines from flooding. This kind of protection is enforced on the owner of a closed mine by the Act of February 4, 1994 on Geological and Mining Law (PRAWO GÓRNICZE I GEOLOGICZNE, 1994). The provisions of the Act are interpreted by mining offices as the obligation to drain mines above the overflow level of the underground reservoirs.

For the need of drainage of closed ore mines, a special pumping station was built at shaft "Bolko" in Bytom, while excavations of disused coal mines are drained using old stationary pumping stations or by means of intakes with underwater pumping units installed in shafts (SZCZEPAŃSKI, 1999). The volume of 
water that is pumped out of excavations is currently $180 \mathrm{~m}^{3} / \mathrm{min}$. The longest draining operations, that is since the 1980s, are those in abandoned excavations of ore mines; these operations may continue until the 2020s, or longer if currently operating coal mines in Bytom receive concessions for further mining. The central pumping station "Bolko", built to comply with the 1980s concessions, was supposed to pump out water at an average rate of $36 \mathrm{~m}^{3} / \mathrm{min}$. Two years after it was built, that is in 1991, almost $90 \%$ of the inflow from the western-side excavations vanished. This was the result of outflow of water, at $4-5 \mathrm{~m}^{3} / \mathrm{min}$., to the Mining Plant "Centrum", which was operating below, because of fracturing of the orogen and deformations caused by mining of coal deposits (KROPKA, 2004). If coal mining carried out by the Mining Plant "Piekary" under old excavations of zinc and lead ores causes large subsidence of terrain, the flow of water to be pumped out on the eastern side will decrease.

Large discrepancies between the intended and actual process of draining of abandoned mining excavations also appeared in closed down mines "Pstrowski", "Kleofas" and "Bytom-Miechowice". This confirms the need to consider also other methods of protection of operating mines from flooding. Assuming that the need for coal does not decrease and current interpretation of the mining law does not change, the process of draining of excavations in closed down mines may go on for as long as 100 years. The consequences of that process which can be predicted include: 1) further contamination of rivers with saline water from mines, 2) incomplete process of convergence of post-mining voids and accompanying fractures, 3) postponed process of rising of the ground water-table and resulting negative effects on the environment.

\section{Consequences of ceased drainage of defunct mines}

After ceasing the process of drainage of mines, water flowing into abandoned excavations will start restoring static resources in the orogen (PosyŁeK \& ROGOŻ, 1998). In areas where deposits have permeable overlying rock (porous Quaternary deposits and fissured Triassic deposits), water reserves will mainly be restored by means of infiltration of precipitation, which will last for several years. In areas where deposits lie under the cover of impermeable Tertiary rock (in the western and southern parts of the conurbation), the inflow of water to excavations and surrounding permeable layers will be mainly based on side inflow by water from neighbouring mines, not covered by impermeable overlying rock, mainly through tectonic fractures and by far circulation water. This is the reason why flooding of mines in those areas will be a long-lasting process, which may take between several and a few dozen years. The process of flooding of mines situated at the depth of 50-100 metres will cause local, secondary residual subsidence of terrain caused by tightening of soaking orogen in zones of old excavations and fractures. Ceased drainage will result in decreased flow in rivers and lower degree of salinity of their water.

After the level of underground water reaches old excavations left by previous shallow mining of ores and coal (usually situated a few dozen metres under the surface), they will start to collapse as a result of soaking of their sidewalls (BIELAŃSKI \& MACUGA, 2000). This will be seen on the surface in the form of discontinuous deformations, mainly depressions, especially in the wide belt of terrain marked by the municipalities of: Zabrze, Orzesze, Jaworzno, Dąbrowa Górnicza. Although many voids left of old mines have been removed, many other voids have not been yet discovered and filled because of a large number of them and lack of documentation regarding their location in case of mines from before 1850. It is also possible that a large number of excavations are situated in the areas which are built up at present.

Also, some of old draining adits, which were closed down mainly by swamping their entrances, will be within the raised level of underground water. It is probable that this will cause an unfavorable outflow of water with simultaneous drainage of a part of post-mining areas, like in case of still operating adits "Kościuszko" and "Gotthelf" in Tarnowskie Góry (LAMPARSKA-WIELAND, 2003)(Fig. 1).

Most problems, however, can be predicted at the final stage of restoration of the underground water table, that is in near-surface deposits overlying old flooded excavations. In regions which are subsided as a result of mining activities, the underground water table will be close to the surface of terrain, reaching basements of buildings, and water will reach the surface in places of deeper subsidence. In such cases, hydrotechnical work will be necessary to enable gravitational downflow or to build pump stations.

Pump stations are already used in some places in order maintain appropriate waste-water management, e.g. in Ruda Śląska - Bykowina, where built-up areas were below the draining level of the Kochłówka river (KLETA ET AL., 2004). After draining of mines which operate in that region ("Pokój", "Wirek", "Halemba") ceases, its flooding will increase, and the lowest-lying parts of the district will probably need reconstruction. 


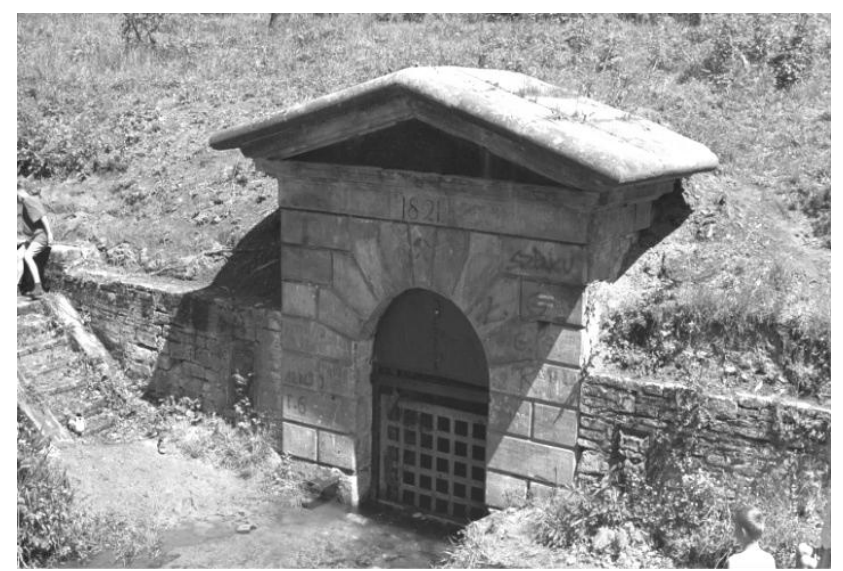

Fig. 1. The mouth of drainage adit "Kościuszko" in Tarnowskie Góry (M. Lamparska-Stobiecka)

A similar situation is that of the terrain, which is mainly agricultural land, near Pyrzowice, which is affected by mining activities of mine "Sośnica" (CEMPIEL, 1998). The Cienka stream drains water from that area to a flood land in a subsidence basin near the improved and raised channel of the Kłodnica river, which lost its draining properties in that section. Water from the flooded land is pumped out to the Kłodnica. After flooding of mine "Sośnica", the terrain around the basin will not be within the raised range of underground water due to the isolating effect of impermeable Tertiary clays. Long-term operation of the pump station may become unprofitable in the future, so the terrain may be reclaimed by filling, after taking all necessary measures to protect the environment.

No such measures were taken in case of reclamation of vast areas in the zone of the largest depressions formed in the southern part of Piekary Śląskie, in the Szarlejka valley (Fig. 2). The lower section of the bed of the river was moved as early as the $19^{\text {th }}$ century, by directing the river through a channel under the city, in order to develop zinc and lead mines "Bleischarley" and iron ore mines "Irena". Later on, intensive underground coal mining activities were carried out in that region, which resulted in large subsidence of terrain. The river lost its draining properties, and as it flowed along high embankments and shifted wastewater from Radzionków and water from flood lands, which was brought mainly from pump stations. Starting from the 1990s, the area of mining subsidence and old open-pit mines have been reclaimed by refilling with barren rock from mines "Julian" and "Andaluzja" as well as with municipal waste and used as industrialcommercial land or road-building land. However, after flooding old excavations remaining after ore mining and gradually terminating coal mines, the restoring underground water level may reach the

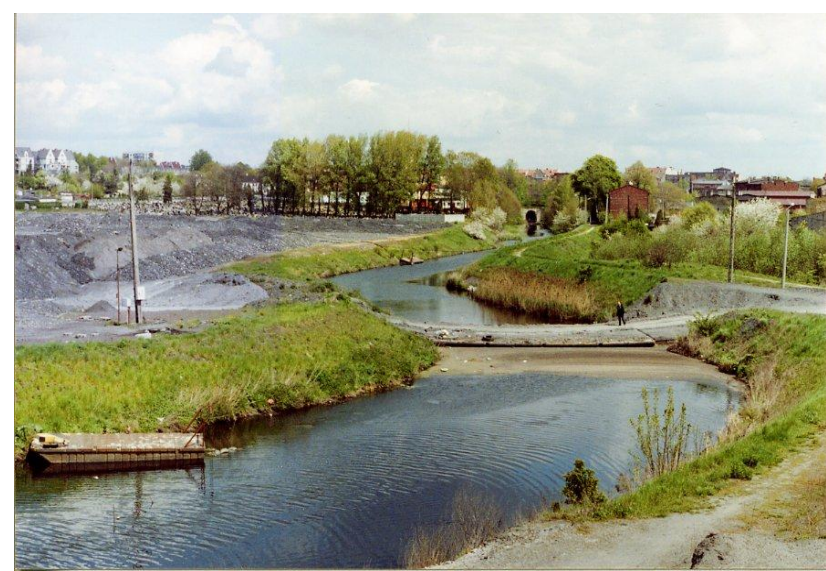

Fig. 2. The reclaimed terrains in the mining subsidence area along Szarlejka Valley (F. Wieland)

highest parts of already reclaimed terrain. With a dense sewage network, excessive water can probably be discharged gravitationally to the nearby Brynica river, but inundations may occur after heavy rains.

Current location of operating coal mines is not favourable for development of the Katowice conurbation. On the northern and southern sides, small-range mining is carried out by mines which only received concessions until the early 2020s in the process of restructurization. In the middle of the conurbation, from Dąbrowa Górnicza to Gliwice, runs a belt of closed down mines, where abandoned workings are drained, and only on the southern side there are mines which operate with high efficiency and have large profitable deposits. The best solution in that situation would be to close down the operating coal mines in the northern and southeastern parts of the conurbation - "BobrekCentrum", "Piekary" and "Kazimierz-Juliusz" as soon as the 2020s. That would make it possible to flood them completely and restore original water coverage and stabilize the orogen. That would result in building land being regained in that part of the conurbation in $20-50$ years, as the hydrological geological-engineering conditions would be stabilized. These areas could serve as land for developing settlement, education, trade, culture, sports and recreation, that is all activities that make up for the vision of modern, post-industrial society. To carry out that project, though, it would be necessary to change legal regulations regarding protection of active mines by owners of closed down mines, as well as refusal of authorities of mining municipalities to extend the concessions for coal mining beyond the early 2020s.

Although some changes in legal regulations are possible, firm opposition of the authorities of municipalities may be hard to obtain. This is mainly because municipalities have some benefits from operation of mines; moreover, they are 
afraid of social discontent caused by making workers of closed mines redundant. Well managed mining companies often persuade municipalities to overtake post-mining land, where the draining of workings is carried out. In case of unfavourable contracts, municipalities may end up having to finance repairs related to mining damage that will occur if draining period for closed mines is extended. Depressions occur in such regions, like it is e.g. in shaft "Krystyna" of the former mine "Michał" in Michałkowice Śląskie.

\section{Summary}

As a result of closing down of some of the mines in the Katowice conurbation, many municipalities lost profits coming from mineral resource mining. Abandoned mines left large areas affected by mining activities in the form of subsidence basins. Post-mining areas cannot be fully used for new economic activities, though. The process of convergence of post-mining voids is still incomplete because of continuous draining of abandoned mines in order to protect operating mines from flooding. Continued draining of mines puts off eventual stabilization of the orogen after mining activities. Current location of operating coal mines in the southern and northern parts of the conurbation with the central belt of drained excavations is not favourable for its sustainable development. The best solution, which would enable further unrestricted growth of the conurbation, would be to close down and flood mines situated on the northern side as soon as their coal mining concessions expire, that is in the early 2020s. Then, within a decade, these areas would restore their original stability and all kinds of building activities could be carried out there. That would, however, require a definite objection of municipalities to extending concessions for mines, which may not happen because of fear of possible social discontent caused by making workers residents of those municipalities - redundant.

\section{References}

Bielański S., Macuga R. 2000. Przydatność terenów pogórniczych miasta Sosnowca do zabudowy. Przegl. Górn., 4: 23-27.

Bilans zasobów kopalini wód podziemnych w Polsce. Mapa rozmieszczenia złóż węgla kamiennego GZW, stan na 31. XII. 2010. Min. Środ., PIG, Warszawa 2011.

Cabała J., Ćmiel S., Idziak A. 2004. Environmental impact of mining activity in the Upper Silesian Coal Basin (Poland). Geol. Belgica, 7/3-4: 225-229.

Cempiel E. 1998. Wpływ poeksploatacyjnych deformacji górotworu na wody gruntowe zlewni Kłodnicy w rejonie Gliwic. [in:] Jankowski A.T. (ed.) Hydrologia obszarów zurbanizowanych i uprzemysłowionych, Wyd. Uniw. Śl., Katowice.

Czaja S. 1999. Zmiany stosunków wodnych $w$ warunkach antropopresji. Wyd. Uniw. Śl., Katowice.

Dulias R. 2003. Subsidence depression in Upper Silesian Coal Basin. Geomorfologický sbornik, 2: 11-16.

Jankowski A.T. 1987. Wpływ urbanizacji I uprzemysłowienia na zmianę stosunków wodnych $\mathrm{w}$ regionie śląskim w świetle dotychczasowych badań. Geogr. St. et dissert., 10: 62-99.

Kleta H., Lamparski H., Lamparska-Wieland M. 2004. Rozwiq̨zanie ujścia wód potoku Bielszowickiego (Kochłówki) nowym tunelem pod wypiętrzanym terenem, na którym zostały usytuowane obiekty zakładu głównego KWK Bielszowice wraz z analizq hydrologicznq zlewni potoku $w$ granicach administracyjnych miasta Ruda Ślacka po wybudowaniu tunelu. SITG Zarz. Gł., Zes. Rzeczozn., Katowice.

Kropka J. 2004. 15 lat centralnego odwadniania wyrobisk zlikwidowanych kopalń rud cynku i ołowiu w niecce bytomskiej. Przegl. Górn., 6: 25-33.

Lamparska-Wieland M. 2003. Atlas zmian wybranych elementów krajobrazu terenów górniczych i pogórniczych Płaskowyżu Tarnowickiego. PWNoZ, 27, Sosnowiec.

Lamparska-Stobiecka M. 2008. Konsekwencje likwidacji kopalń węgla kamiennego przez zatopienie dla konurbacji górnośląskiej. Kształt. środ. geogr. i ochr. przyr. na obsz. uprzem. i zurb., 39: 32-44.

Posyłek E., Rogoż M. 1998. Przewidywane zmiany warunków hydrogeologicznych związane $\mathrm{z}$ likwidacją kopalń $\mathrm{w}$ Górnośląskim Zagłębiu Węglowym. [in:] Jankowski A. T. (ed.) Hydrologia obszarów zurbanizowanych i uprzemysłowionych. Wyd. Uniw. Śl., Katowice.

Prawo geologiczne i górnicze, Ustawa z dnia 4 lutego 1994 r. Dz.U. 1994 nr 27 poz. 96, z późniejszymi zmianami.

Solarski M., Pradela A. 2010. Przemiany wybranych form rzeźby Wyżyny Miechowickiej w latach 1883-1994. Z badań nad wpływem antropopr. na środ., 11: 78-92.

Szczepański A. 1999. Hydrogeologiczne uwarunkowania likwidacji zakładów górniczych. Przegl. Górn., 7-8: 25-30.

Wilk Z. (ed.). 2003. Hydrogeologia polskich złóż kopalin i problemy wodne górnictwa. T. 1, Uczel. Wyd. Nauk.-Dydakt., Kraków. 